\title{
Association Between Basal Platelet Count and All- cause Mortality in Critically III Patients With Acute Respiratory Failure: a Secondary Analysis From the eICU Collaborative Research Database
}

\section{Chuan Xiao}

The Affiliated Hospital of Guizhou Medical University

\section{Zuoan Qin}

The First People's Hospital of Changde City

Jingjing Xiao

The Affiliated Hospital of Guizhou Medical University

\section{Yumei Cheng}

The Affiliated Hospital of Guizhou Medical University

Qing Li

The Affiliated Hospital of Guizhou Medical University

Wei Li

The Affiliated Hospital of Guizhou Medical University

Tianhui He

The Affiliated Hospital of Guizhou Medical University

Shuwen Li

The Affiliated Hospital of Guizhou Medical University

Daixiu Gao

The Affiliated Hospital of Guizhou Medical University

Shen Feng ( $\nabla$ doctorshenfeng@163.com )

The Affiliated Hospital of Guizhou Medical University

\section{Research Article}

Keywords: ICU, Acute respiratory failure, Platelet count, Mortality

Posted Date: August 10th, 2021

DOl: https://doi.org/10.21203/rs.3.rs-786800/v1

License: (c) (i) This work is licensed under a Creative Commons Attribution 4.0 International License. 
Page 2/17 


\section{Abstract}

Background: There is limited evidence on the correlation between platelet counts and all-cause mortality in critically ill patients with acute respiratory failure (ARF). The aim was to evaluate whether platelet count was associated with all-cause mortality in critical patients with ARF by using the elCU Collaborative Research Database.

Methods: Using a retrospective multicenter cohort dataset, data of 26961 patients with ARF in ICU between 2014 and 2015 were collected. The independent variable was log2 basal platelet count, and the dependent variables were all-cause mortality in hospital and in ICU. Covariates included demographic data, Acute Physiology and Chronic Health Evaluation (APACHE) IV score, supportive treatment, and comorbidities.

Results: In fully adjusted model, log2 basal platelet count was negatively associated with all-cause mortality both in hospital [ RR:0.87, 95\% Cl: 0.84 - 0.91] or in ICU [RR: $0.87,95 \% \mathrm{Cl}: 0.83,0.92$ ]. By nonlinearity test, the relationship between log2 basal platelet count and all-cause mortality in hospital and in ICU were nonlinear. The inflection point we got was 6.83 and 6.86 (after inverse log2 logarithmic conversion, the platelet count are $114 \times 10^{9} / \mathrm{L}$ and $116 \times 10^{9} / \mathrm{L}$ ). There was no a correlation between blood platelets and all-cause mortality in hospital on the right side of the inflection point, (RR:0.96, 95\% Cl: 0.88 1.03) and in ICU (RR:0.97, 95\% Cl: 0.91-1.04).

Conclusions: For patients with ARF in ICU, platelet count was negatively associated with all-cause mortality in hospital and in ICU when platelet count is less than $114 \times 10^{9} / \mathrm{L}$ and $116 \times 10^{9} / \mathrm{L}$ respectively, but when the platelet count was higher, we failed to observe a correlation between them. The safe ranges of platelet count we detected were $78 \times 10^{9} / \mathrm{L}-145 \times 10^{9} / \mathrm{L}$ and $89 \times 10^{9} / \mathrm{L}-147 \times 10^{9} / \mathrm{L}$ respectively.

\section{Introduction}

Platelets are unnucleated fragments derived from megakaryocytes ${ }^{1}$. Traditionally, platelet is regarded as to be responsible for hemostasis in response to vascular injury and endothelial disruption ${ }^{2}$. However, besides that, platelets have many other functions, among which participating in the inflammatory process is one of the most important functions ${ }^{3}$. Many studies have proved that platelets participate in the pathogenesis of many inflammation-related clinical disease ${ }^{3-5}$, including respiratory system, rheumatic system, gastrointestinal system and other diseases 6,7 . Therefore, platelets can be used as potentially important clinical indicators for the monitoring of disease progression. The most common complication of platelet abnormalities in ICU is thrombocytopenia ${ }^{8}$, which is a risk factor for the development of organ failure and vascular leakage. Occurrence and development of thrombocytopenia is associated with increased mortality in critically ill patient 9,10,11.

Acute respiratory failure(ARF) is one of the common life-threatening complications in intensive care unit patients, often accompanied by changes in platelet count ${ }^{12}$. The mechanism may be that part of platelets 
is originally derived from the lung tissue ${ }^{12-14}$, indicated by 1) megakaryocytes are also found in the lung tissue $\left.^{15}, 2\right)$ platelet counts are higher in the left side of the heart than in the right side of the heart, implying platelet genesis in the pulmonary tissue ${ }^{16}$, and 3) in many severe cases such as ARF, thrombocytosis is often occurred first, and then followed by thrombocytopenia ${ }^{17}$.

However, the relationship between platelet count and prognosis in ARF patients has been controversial, and the real relationship was actually difficult to be drawn because of the limited methodology. Therefore, we used the large sample library of eICU to explore the relationship between platelet count and all-cause mortality in hospitals and in ICU for patients with ARF.

\section{Participants And Methods}

\section{Data source}

The data of our analysis came from the elCU of Collaborative Research Database (eICU-CRD). The dataset included 200,859 ICU admissions between 2014 and 2015. These patients were collected from 208 hospitals across the United States. The data contained in the elCU-CRD are of high quality. Most variables are close to complete, with little missingness in the routinely collected fields ${ }^{18},{ }^{19}$. The ethics of elCU has been approved. For details, please refer to the official website (https://eicu-crd.mit.edu). After finishing the web-based training courses and Protecting Human Research Participant sex amination (No.36208651), we obtained permission to extract data from the elCU-CRD.

\section{Study design}

This is a secondary analysis based on a multicenter cohort dataset. The target independent variable is log2 basal blood platelet count and recorded as a continuous variable. The outcome variables are allcause mortality in hospital and in ICU, respectively. Both are recorded as binary variables ( 0 survival, 1 non-survival)

\section{Study population}

The data of ARF were collected from 208 hospitals across the United States. To ensure the privacy of participants, database generators encode the patient's identity information as nontraceable codes. A total of 200,859 ICU patients were initially included, of whom 26961 were eventually screened to be analyzed. (Fig. 1). The collection time of participants started 2014 and ended in 2015, respectively. Patients were excluded for the following reasons: (1) Missing hospital mortality data, (2) Missing basal platelet count information.

\section{Clinical variables and outcomes}

In the present study, the dependent variable was basal platelet count data. Targeted independent variables were all-cause mortality in hospital and in ICU. Covariates were used as follows : continuous variables consisted of age (years), albumin ( $\mathrm{g} / \mathrm{L})$, body mass index (BMI, $\left.\mathrm{kg} / \mathrm{m}^{2}\right)$, APACHE IV score. 
Categorical variables consist of sex, race / ethnicity, congestive heart failure, COPD, diabetes, coagulation disease, mechanical breathing, oxygen therapy, antiplatelet drugs. In general, the covariates included demographic data, comorbidities, severity of illness,and life support interventions, etc.

\section{Statistical analysis}

Given that the platelet count is a skewed distribution, we log2 transform it to be close to a normal distribution. We use mean \pm standard deviation (SD) to represent continuous variables, median (range) (skew distribution), no. (\%) to represent categorical variables). Chi-square test (categorical variables) or One-way ANOVA (continuous variables) were employed to calculate the differences among different platelet count groups (quartile of log2 platelet count). We investigated whether the platelet count is related to the mortality of selected participants in hospitals and ICUs. Our statistical method is divided into 3 steps.

Step 1: We used Univariate and multivariate binary logistic regression models and constructed three distinct models: including non-adjusted model (no covariates were adjusted), minimally-adjusted model (only social demography variables were adjusted), and fully adjusted model (adjusted the covariates in Table 1). Step 2: Considering that logistic regression cannot handle the nonlinear relationship, and the possibility of a nonlinear relationship between log2 platelet count and death cannot be ruled out, we used the smooth curve fitting to address the nonlinearity. We use a recursive algorithm to calculate the inflection point, if non-linearity is detected, the range of the inflection point using bootstrapping to calculate the credible interval, and construct two piecewise linear regression models on both sides of the inflection point. The determination of the best fit model (linear regression model and two-stage linear regression model) was based on the $\mathrm{P}$ value of the log-likelihood ratio test. Step 3: We did a sensitivity analysis by converting the log2 platelet count into a categorical variable by quartile to ensure the robustness of data. 
Table 1

Baseline characteristics of participants 26961

\begin{tabular}{|c|c|c|c|c|c|}
\hline log2 platelet count & Q1 & Q2 & Q3 & Q4 & $\begin{array}{l}\mathrm{P} \text { - } \\
\text { value }\end{array}$ \\
\hline $\mathrm{N}$ & 6719 & 6661 & 6836 & 6745 & \\
\hline Age, mean $\pm S D$, year & $\begin{array}{l}65.20 \pm \\
15.16\end{array}$ & $\begin{array}{l}64.97 \pm \\
15.87\end{array}$ & $\begin{array}{l}63.66 \pm \\
16.59\end{array}$ & $\begin{array}{l}62.93 \pm \\
16.75\end{array}$ & $\begin{array}{l}< \\
0.001\end{array}$ \\
\hline $\mathrm{BMI}(\mathrm{kg} / \mathrm{m} 2)$ & $27.31 \pm 8.74$ & $27.92 \pm 8.67$ & $27.62 \pm 8.69$ & $26.89 \pm 8.54$ & $\begin{array}{l}< \\
0.001\end{array}$ \\
\hline Albumin & $2.84 \pm 0.72$ & $3.09 \pm 0.69$ & $3.14 \pm 0.72$ & $3.00 \pm 0.77$ & $<0.001$ \\
\hline APACHE- $囚$ score & $\begin{array}{l}78.55 \pm \\
32.03\end{array}$ & $\begin{array}{l}69.95 \pm \\
29.35\end{array}$ & $\begin{array}{l}69.39 \pm \\
28.84\end{array}$ & $\begin{array}{l}70.21 \pm \\
28.58\end{array}$ & <. 001 \\
\hline $\operatorname{Sex}(n, \%)$ & & & & & $<0.001$ \\
\hline male & $\begin{array}{l}4046 \\
(60.24 \%)\end{array}$ & $\begin{array}{l}3759 \\
(56.45 \%)\end{array}$ & $\begin{array}{l}3452 \\
(50.51 \%)\end{array}$ & $\begin{array}{l}3027 \\
(44.89 \%)\end{array}$ & \\
\hline female & $\begin{array}{l}2671 \\
(39.76 \%)\end{array}$ & $\begin{array}{l}2900 \\
(43.55 \%)\end{array}$ & $\begin{array}{l}3382 \\
(49.49 \%)\end{array}$ & $\begin{array}{l}3716 \\
(55.11 \%)\end{array}$ & \\
\hline Race & & & & & $\begin{array}{l}< \\
0.001\end{array}$ \\
\hline African-American & $\begin{array}{l}741 \\
(11.11 \%)\end{array}$ & $\begin{array}{l}731 \\
(11.08 \%)\end{array}$ & $\begin{array}{l}842 \\
(12.40 \%)\end{array}$ & $\begin{array}{l}697 \\
(10.41 \%)\end{array}$ & \\
\hline Asian & $91(1.36 \%)$ & $110(1.67 \%)$ & $99(1.46 \%)$ & $100(1.49 \%)$ & \\
\hline Caucasian & $\begin{array}{l}5020 \\
(75.30 \%)\end{array}$ & $\begin{array}{l}5069 \\
(76.83 \%)\end{array}$ & $\begin{array}{l}5074 \\
(74.69 \%)\end{array}$ & $\begin{array}{l}5184 \\
(77.44 \%)\end{array}$ & \\
\hline Hispanic & $411(6.16 \%)$ & $367(5.56 \%)$ & $426(6.27 \%)$ & $386(5.77 \%)$ & \\
\hline $\begin{array}{l}\text { U.S. native military and } \\
\text { civilian }\end{array}$ & $87(1.30 \%)$ & $46(0.70 \%)$ & $49(0.72 \%)$ & $48(0.72 \%)$ & \\
\hline Unknown & $317(4.75 \%)$ & $275(4.17 \%)$ & $303(4.46 \%)$ & $279(4.17 \%)$ & \\
\hline Congestive heart failure & & & & & $\begin{array}{l}<.001 \\
0.00\end{array}$ \\
\hline No & $\begin{array}{l}5694 \\
(84.74 \%)\end{array}$ & $\begin{array}{l}5481 \\
(82.28 \%)\end{array}$ & $\begin{array}{l}5698 \\
(83.35 \%)\end{array}$ & $\begin{array}{l}5703 \\
(84.55 \%)\end{array}$ & \\
\hline
\end{tabular}

Mean +/-SD for continuous variables: $P$ value was calculated by weighted linear regression model $\%$ for Categorical variables: $\mathrm{P}$ value was calculated by weighted chi-square test 


\begin{tabular}{|c|c|c|c|c|c|}
\hline $\log 2$ platelet count & Q1 & Q2 & Q3 & Q4 & $\begin{array}{l}\mathrm{P} \text { - } \\
\text { value }\end{array}$ \\
\hline Yes & $\begin{array}{l}1025 \\
(15.26 \%)\end{array}$ & $\begin{array}{l}1180 \\
(17.72 \%)\end{array}$ & $\begin{array}{l}1138 \\
(16.65 \%)\end{array}$ & $\begin{array}{l}1042 \\
(15.45 \%)\end{array}$ & \\
\hline COPD & & & & & $\begin{array}{l}< \\
0.001\end{array}$ \\
\hline No & $\begin{array}{l}5756 \\
(85.67 \%)\end{array}$ & $\begin{array}{l}5424 \\
(81.43 \%)\end{array}$ & $\begin{array}{l}5616 \\
(82.15 \%)\end{array}$ & $\begin{array}{l}5664 \\
(83.97 \%)\end{array}$ & \\
\hline Yes & $\begin{array}{l}963 \\
(14.33 \%)\end{array}$ & $\begin{array}{l}1237 \\
(18.57 \%)\end{array}$ & $\begin{array}{l}1220 \\
(17.85 \%)\end{array}$ & $\begin{array}{l}1081 \\
(16.03 \%)\end{array}$ & \\
\hline Mechanical breathing & & & & & $\begin{array}{l}< \\
0.001\end{array}$ \\
\hline No & $\begin{array}{l}2340 \\
(34.83 \%)\end{array}$ & $\begin{array}{l}2500 \\
(37.53 \%)\end{array}$ & $\begin{array}{l}2587 \\
(37.84 \%)\end{array}$ & $\begin{array}{l}2506 \\
(37.15 \%)\end{array}$ & \\
\hline Yes & $\begin{array}{l}4379 \\
(65.17 \%)\end{array}$ & $\begin{array}{l}4161 \\
(62.47 \%)\end{array}$ & $\begin{array}{l}4249 \\
(62.16 \%)\end{array}$ & $\begin{array}{l}4239 \\
(62.85 \%)\end{array}$ & \\
\hline Diabetes & & & & & 0.013 \\
\hline No & $\begin{array}{l}5726 \\
(85.22 \%)\end{array}$ & $\begin{array}{l}5594 \\
(83.98 \%)\end{array}$ & $\begin{array}{l}5700 \\
(83.38 \%)\end{array}$ & $\begin{array}{l}5725 \\
(84.88 \%)\end{array}$ & \\
\hline Yes & $\begin{array}{l}993 \\
(14.78 \%)\end{array}$ & $\begin{array}{l}1067 \\
(16.02 \%)\end{array}$ & $\begin{array}{l}1136 \\
(16.62 \%)\end{array}$ & $\begin{array}{l}1020 \\
(15.12 \%)\end{array}$ & \\
\hline Sepsis & & & & & $<.001$ \\
\hline No & $\begin{array}{l}4776 \\
(71.08 \%)\end{array}$ & $\begin{array}{l}5145 \\
(77.24 \%)\end{array}$ & $\begin{array}{l}5317 \\
(77.78 \%)\end{array}$ & $\begin{array}{l}4750 \\
(70.42 \%)\end{array}$ & \\
\hline Yes & $\begin{array}{l}1943 \\
(28.92 \%)\end{array}$ & $\begin{array}{l}1516 \\
(22.76 \%)\end{array}$ & $\begin{array}{l}1519 \\
(22.22 \%)\end{array}$ & $\begin{array}{l}1995 \\
(29.58 \%)\end{array}$ & \\
\hline Oxygen-therapy & & & & & 0.940 \\
\hline No & $\begin{array}{l}4406 \\
(65.58 \%)\end{array}$ & $\begin{array}{l}4364 \\
(65.52 \%)\end{array}$ & $\begin{array}{l}4477 \\
(65.49 \%)\end{array}$ & $\begin{array}{l}4448 \\
(65.95 \%)\end{array}$ & \\
\hline Yes & $\begin{array}{l}2313 \\
(34.42 \%)\end{array}$ & $\begin{array}{l}2297 \\
(34.48 \%)\end{array}$ & $\begin{array}{l}2359 \\
(34.51 \%)\end{array}$ & $\begin{array}{l}2297 \\
(34.05 \%)\end{array}$ & \\
\hline Antiplatelet drugs & & & & & 0.012 \\
\hline No & $\begin{array}{l}6317 \\
(94.02 \%)\end{array}$ & $\begin{array}{l}6184 \\
(92.84 \%)\end{array}$ & $\begin{array}{l}6343 \\
(92.79 \%)\end{array}$ & $\begin{array}{l}6304 \\
(93.46 \%)\end{array}$ & \\
\hline
\end{tabular}

Mean +/-SD for continuous variables: $P$ value was calculated by weighted linear regression model $\%$ for Categorical variables: $\mathrm{P}$ value was calculated by weighted chi-square test 


\begin{tabular}{|lcllll|}
\hline log2 platelet count & Q1 & Q2 & Q3 & Q4 & $\begin{array}{l}\text { P- } \\
\text { value }\end{array}$ \\
\hline Yes & $402(5.98 \%)$ & $477(7.16 \%)$ & $493(7.21 \%)$ & $441(6.54 \%)$ & \\
\hline Coagulation disease & & & & 0.001 \\
\hline No & 6209 & 6395 & 6602 & 6535 \\
& $(92.41 \%)$ & $(96.01 \%)$ & $(96.58 \%)$ & $(96.89 \%)$ \\
\hline Yes & $510(7.59 \%)$ & $266(3.99 \%)$ & $234(3.42 \%)$ & $210(3.11 \%)$ \\
\hline Mean +/-SD for continuous variables: P value was calculated by weighted linear regression model \\
\hline \% for Categorical variables: P value was calculated by weighted chi-square test \\
\hline
\end{tabular}

We performed the analyses with the statistical software packages R (http://www.R-project.org, The R Foundation) and EmpowerStats (http://www. empowerstats.com, X\&Y Solutions, Inc, Boston, MA). Statistically significant in $p<0.05$ (both sides).

\section{Results}

\section{Baseline characteristics of participants}

The participants of baseline characteristics is shown in Table 1. The mean age was $64.23 \pm 16.14$ years, $52.99 \%$ were male. All-cause mortality in hospital and in ICU is $21.48 \%$ and $14.24 \%$, respectively. Compared with patients in Q2-Q4, patients in Q1 were elder, mostly male, and had a higher APACHE IV score with a higher proportion of mechanical ventilation and a lower proportion of congestive heart failure, COPD, diabetes and the use of anticoagulant drugs.

\section{Blood platelet count and all-cause mortality in hospital and in ICU}

We listed the effect sizes and $95 \%$ confidence interval $(95 \% \mathrm{Cl})$ in Table 2. Model 1 (unadjusted model) indicated that all-cause mortality in hospital (RR: $0.73,95 \% \mathrm{Cl}: 0.70-0.75)$ and in ICU (RR: $0.71,95 \% \mathrm{Cl}$ : $0.69-0.74)$ were negatively associated with log2 platelet count. These results were verified by sensitivity analysis. Similar results can be detected in adjusted model 2 (socio-demographic variables such as age, sex, race/ethnicity), i.e., a negative association between log2 platelet count and all-cause mortality both in hospital (RR: $0.72,95 \% \mathrm{Cl}: 0.70-0.75)$ and in ICU (RR: $0.71,95 \% \mathrm{Cl}: 0.68-0.74)$ were also existed. In model 3 (fully-adjusted model), log2 platelet count was still shown to be negatively correlated with allcause mortality in hospital (RR: $0.87,95 \% \mathrm{Cl}$ : $0.84-0.91$ ) and in ICU (RR: $0.87,95 \% \mathrm{Cl}: 0.83-0.92)$ when all covariates presented in Table 1 were adjusted. 
Table 2

Results of univariate and multivariate analysis

\begin{tabular}{|c|c|c|c|}
\hline Exposure & $\begin{array}{l}\text { Non-adjusted model } \\
\text { Effect size }(95 \% \mathrm{Cl})\end{array}$ & $\begin{array}{l}\text { Minimally-adjusted } \\
\text { model } \\
\text { Effect size }(95 \% \mathrm{Cl})\end{array}$ & $\begin{array}{l}\text { Fully-adjusted model } \\
\text { Effect size }(95 \% \mathrm{Cl})\end{array}$ \\
\hline \multicolumn{4}{|l|}{$\begin{array}{l}\text { Mortality in } \\
\text { Hospital }\end{array}$} \\
\hline Log2 Platelets & $\begin{array}{l}0.73(0.70,0.75)< \\
0.00001\end{array}$ & $\begin{array}{l}0.72(0.70,0.75)< \\
0.00001\end{array}$ & $\begin{array}{l}0.87(0.84,0.91)< \\
0.00001\end{array}$ \\
\hline \multicolumn{4}{|l|}{$\begin{array}{l}\text { Log2 Platelets } \\
\text { group }\end{array}$} \\
\hline Q1 & 1.0 & 1.0 & 1.0 \\
\hline Q2 & $\begin{array}{l}0.64(0.59,0.69)< \\
0.0001\end{array}$ & $\begin{array}{l}0.63(0.58,0.69)< \\
0.0001\end{array}$ & $0.88(0.79,0.98) 0.0181$ \\
\hline Q3 & $\begin{array}{l}0.58(0.53,0.63)< \\
0.0001\end{array}$ & $\begin{array}{l}0.59(0.54,0.64)< \\
0.0001\end{array}$ & $0.83(0.74,0.92) 0.0002$ \\
\hline Q4 & $\begin{array}{l}0.64(0.59,0.70)< \\
0.0001\end{array}$ & $\begin{array}{l}0.67(0.61,0.72)< \\
0.0001\end{array}$ & $0.85(0.76,0.94) 0.0009$ \\
\hline$P$ for trends & $<0.0001$ & $<0.0001$ & 0.0007 \\
\hline \multicolumn{4}{|l|}{ Mortality in ICU } \\
\hline Log2 Platelets & $\begin{array}{l}0.71(0.69,0.74)< \\
0.00001\end{array}$ & $\begin{array}{l}0.71(0.68,0.74)< \\
0.00001\end{array}$ & $\begin{array}{l}0.87(0.83,0.92)< \\
0.00001\end{array}$ \\
\hline \multicolumn{4}{|l|}{$\begin{array}{l}\text { Log2 Platelets } \\
\text { group }\end{array}$} \\
\hline Q1 & 1.0 & 1.0 & 1.0 \\
\hline Q2 & $\begin{array}{l}0.66(0.60,0.72)< \\
0.0001\end{array}$ & $\begin{array}{l}0.66(0.60,0.72)< \\
0.0001\end{array}$ & $0.90(0.80,1.02) 0.0973$ \\
\hline Q3 & $\begin{array}{l}0.57(0.52,0.63)< \\
0.0001\end{array}$ & $\begin{array}{l}0.58(0.52,0.64)< \\
0.0001\end{array}$ & $0.85(0.75,0.95) 0.0013$ \\
\hline Q4 & $\begin{array}{l}0.62(0.56,0.68)< \\
0.0001\end{array}$ & $\begin{array}{l}0.64(0.58,0.70)< \\
0.0001\end{array}$ & $0.83(0.74,0.94) 0.0031$ \\
\hline$P$ for trends & $<0.0001$ & $<0.0001$ & 0.0018 \\
\hline \multicolumn{4}{|c|}{ Non-adjusted model: we do not adjust for any covariates } \\
\hline
\end{tabular}


The results about the nonlinearity of log2 platelet count and all-cause mortality both in ICU and in hospital were shown in Fig. 2, Fig. 3, and Table 3, respectively. By recursive algorithm, we got the inflection points for log2 platelet count (6.83 and 6.86), the credible intervals of the inflection points are $6.29-7.18$ and $6.48-7.2$ respectively. To facilitate clinical application, we have carried out an inverse log2 logarithmic conversion. Therefore, the inflection points are $114 \times 10^{9} / \mathrm{L}$ and $116 \times 10^{9} / \mathrm{L}$, wiht the confidence intervals of $78 \times 10^{9} / \mathrm{L}-145 \times 10^{9} / \mathrm{L}$ and $89 \times 10^{9} / \mathrm{L}-147 \times 10^{9} / \mathrm{L}$ respectively.

Table3

Nonlinearity explanation on log2 platelet count and all-cause mortality in hospital and in ICU using twopiecewise linear model

\begin{tabular}{|lll|}
\hline & $\begin{array}{l}\text { Mortality in ICU } \\
\text { Effect size }(95 \% \mathrm{Cl}) P \\
\text { value }\end{array}$ & $\begin{array}{l}\text { Mortality in Hospital } \\
\text { Effect size }(95 \% \mathrm{Cl}) \mathrm{P} \\
\text { value }\end{array}$ \\
\hline Fitting model using & $\begin{array}{l}0.87(0.82,0.91) \\
<0.00001\end{array}$ & $\begin{array}{l}0.86(0.82,0.89) \\
<0.00001\end{array}$ \\
\hline I model & & \\
\hline $\begin{array}{l}\text { Fitting model using two-piecewise linear } \\
\text { model }\end{array}$ & $6.83(6.29-7.18)$ & $6.86(6.48-7.2)$ \\
\hline Inflection point (log2 platelet count) * & $0.75(0.68,0.83)<0.0001$ & $0.70(0.63,0.77)<0.0001$ \\
\hline$<$ Inflection point & $0.96(0.88,1.03) 0.2608$ & $0.97(0.91,1.04) 0.5190$ \\
\hline$>$ Inflection point & $<0.001$ & $<0.001$ \\
\hline P for log likely ratio test & $114(78-145)$ & $116(89-147)$ \\
\hline Inflection point (platelet count) * * & & \\
\hline The adjustment strategy is the same with fully-adjusted model & \\
\hline \#, the inflection point of the platelet count is obtained by log2 inverse logarithmic conversion
\end{tabular}

Two-piecewise Logistic regression model showed that to the left of the turning point, for every 1 unit increase in log2 platelet count, the risk of hospital mortality decreases by $25 \% \triangle \mathrm{RR}: 0.75,95 \% \mathrm{Cl}$ : 0.68 0.83 \and the risk of ICU mortality decreases by $30 \% \bigotimes$ RR: $0.70,95 \% \mathrm{Cl}: 0.63-0.77 \rrbracket$. Conversely, on the right side of the inflection point, the log2 platelet count increase does not further reduce hospital mortality anymore『RR:0.96, 95\% Cl:0.88-1.03ه, prompting a saturation effect.

\section{Discussion}


This retrospective cohort study investigated the relationship between platelet counts and all-cause mortality in hospitals and in ICUs in patients with ARF. Our results showed that after controlling for age, sociodemographic factors, comorbidities, and interventions, platelet count in severe ARF patients was negatively correlated with all-cause mortality in hospital and in ICU in a condition of platelet count less than certain range. However, the nonlinearity test demonstrated that the association between platelet count and mortality presents a saturation effect, that is, within a certain range, the increase of platelet count can reduce the risk of death, but if platelet count is respectively more than $114 \times 10^{9} / \mathrm{L}$ and $116 \times 10^{9} / L$, the negative relationship between mortality and platelet count would disappear.

Clinical studies have shown that patients with ARF are often accompanied by thrombocytopenia, which is associated with adverse events and increased risk of mortality. Matthew et al. found a strong relationship existed between hematologic failure (manifested by thrombocytopenia) and mortality in populations with ARF treated with mechanical ventilation ${ }^{20}$. The PROTECT trial enrolling 3721 patients showed that patients with moderate and severe thrombocytopenia more likely had subsequent bleeding and received transfusions, and more importantly, were more vulnerable to die during ICU or hospital stay when compared to patients without thrombocytopenia ${ }^{21}$. Juan et al. reported in a prospective observational study that ARF patients with H1N1 influenza complicated with thrombocytopenia had a lower in-hospital survival rate 22 . Our results were consistent with those of the above studies. However, linear other than nonlinear correlations between platelet count and mortality were explored in these studies, which, we think, were inconsistent with the real situation in the human body.. On the contrary, in our study, we used a nonlinear model to analyse the relationship between platelet count and all-cause mortality in ARF patients, and the results demonstrated that platelet count was negatively correlated with mortality in hospital and in ICU only when platelet count were less than $114 \times 10^{9} / \mathrm{L}$ and $116 \times 10^{9} / \mathrm{L}$ respectively. Once the patient's platelet count exceeded these ranges, the negative correlation disappeared. From the correlation analysis figure, we detected that the safe range of platelet count were $78 \times 10^{9} / \mathrm{L}-145 \times 10^{9} / \mathrm{L}$ for hopital stay and $89 \times 10^{9} / \mathrm{L}-147 \times 10^{9} / \mathrm{L}$ for ICU stay respectively.

The mechanisms of thrombocytopenia in patients with ARF are associated with several aspects, including 1) suppression of stem cell/progenitor cell function in the hematopoietic system $\left.{ }^{23-26}, 2\right)$ decreased thrombopoietin (TPO) production,3) imbalance between platelet consumption and production $₫ 4$ ) dysfunctional bone marrow microenvironment and 5) lung damage $14,27,28$.

Our research has certain advantages. First, the sample size of this research is relatively large. Second, our data from a multicenter ICU, making the results credible for general ICU patients with ARF. Third, we performed sensitivity analysis by converting log2 platelet count into categorical variables by quartiles to improve data robustness. Finally, a two-part linear model was used to observe the saturation effect between log2 platelet count and all-cause mortality in hospitals and ICUs.

However, our study also has some shortcomings. Firstly, the study population is mainly from America, making the possibility of regional or State's bias. Secondly, like other clinical studies, some unmeasured 
confounders are not controlled in our data, which inevitably influence the analysis results. Thirdly, this research is a secondary mining of public databases, in which the adjustment strategy of covariates is limited by the database.

\section{Conclusions}

Our results demonstrated that platelet count was negatively associated with all-cause mortality in hospital and in ICU in critically ill patients with ARF when platelet count is less than $114 \times 10^{9} / \mathrm{L}$ and 116 $\times 10^{9} / \mathrm{L}$ respectively. For AFR patients in ICU, the safe ranges of platelet count were $78 \times 10^{9} / \mathrm{L}-145 \times 10^{9} / \mathrm{L}$ and $89 \times 10^{9} / \mathrm{L}-147 \times 10^{9} / \mathrm{L}$.

\section{Declarations}

\section{- Ethical Approval and consent to participate}

The study has been approved by the Ethics Committee of Affiliated Hospital of Guizhou Medical University .

\section{- Declaration of Conflicting Interests}

There were no potential conflicts of interest.

\section{- Funding}

No funding.

\section{- Authors' contributions}

CX contributed to study concept and design, drafting of the manuscript. ZAQ constructed and cleared data. JJX, MYC, LQ, LW, HTH, LSW and GDX help with data arrangement. FS contributed to the study concept, supervision and organized the final manuscript.

\section{- Data availability statement}

The data are available on the elCU- CRD website at https://eicu-crd.mit.edu

\section{- Competing interests}

There was no competing interests in authors.

\section{References}

1. Cunin P, Bouslama R, Machlus KR, et al. Megakaryocyte emperipolesis mediates membrane transfer from intracytoplasmic neutrophils to platelets. Elife. 2019;8. 
2. Clemons Bankston P, Al-Horani RA. New Small Molecule Drugs for Thrombocytopenia: Chemical, Pharmacological, and Therapeutic Use Considerations. Int J Mol Sci. 2019;20(12).

3. Thachil J. Platelets in Inflammatory Disorders: A Pathophysiological and Clinical Perspective. Semin Thromb Hemost. 2015;41(6):572-81.

4. Chou TC. New mechanisms of antiplatelet activity of nifedipine, an L-type calcium channel blocker. Biomedicine (Taipei). 2014;4:24.

5. de Stoppelaar SF, van 't Veer C, Claushuis TA, Albersen BJ, Roelofs JJ, van der Poll T. Thrombocytopenia impairs host defense in gram-negative pneumonia-derived sepsis in mice. Blood. 2014;124(25):3781-90.

6. Vigne J, Bay S, Aid-Launais R, et al. Cleaved CD31 as a target for in vivo molecular imaging of inflammation. Sci Rep. 2019;9(1):19560.

7. Linlin Chen HD, Hengmin Cui $\mathrm{W}$ Jing Fang. Inflammatory responses and inflammation-associated diseases in organs. Oncotarget. 2018; 9, (No. 6), pp: 7204-7218.

8. Zhou D, Li Z, Wu L, Shi G, Zhou J. Thrombocytopenia and platelet course on hospital mortality in neurological intensive care unit: a retrospective observational study from large database. BMC Neurol. 2020;20(1):220.

9. Sezgi C, Taylan M, Kaya H, et al. Alterations in platelet count and mean platelet volume as predictors of patient outcome in the respiratory intensive care unit. Clin Respir J. 2015; 9(4):403-8.

10. Ali N, Auerbach HE. New-onset acute thrombocytopenia in hospitalized patients: pathophysiology and diagnostic approach. J Community Hosp Intern Med Perspect. 2017; 7(3):157-67.

11. Thachil J, Warkentin TE. How do we approach thrombocytopenia in critically ill patients? $\mathrm{Br} \mathrm{J}$ Haematol. 2017;177(1):27-38.

12. Bozza FA, Shah AM, Weyrich AS, Zimmerman GA. Amicus or adversary: platelets in lung biology, acute injury, and inflammation. Am J Respir Cell Mol Biol. 2009;40(2):123-34.

13. Lefrancais E, Ortiz-Munoz G, Caudrillier A, et al. The lung is a site of platelet biogenesis and a reservoir for haematopoietic progenitors. Nature. 2017;544(7648):105-9.

14. Lefrancais E, Looney MR. Platelet Biogenesis in the Lung Circulation. Physiology (Bethesda). 2019;34(6):392-401.

15. Stolla MC, Catherman SC, Kingsley PD, et al. Lin28b regulates age-dependent differences in murine platelet function. Blood Adv. 2019;3(1):72-82.

16. Thachil J, Lisman T. Pulmonary Megakaryocytes in Coronavirus Disease 2019 (COVID-19): Roles in Thrombi and Fibrosis. Semin Thromb Hemost. 2020;46(7):831-4.

17. Yang $\mathrm{M}, \mathrm{Ng} \mathrm{MH}, \mathrm{Li} \mathrm{CK}$, et al. Thrombopoietin levels increased in patients with severe acute respiratory syndrome. Thromb Res. 2008;122(4):473-7.

18. O'Halloran HM, Kwong K, Veldhoen RA, Maslove DM. Characterizing the Patients, Hospitals, and Data Quality of the eICU Collaborative Research Database. Crit Care Med. 2020; 48(12):1737-43. 
19. Pollard TJ, Johnson AEW, Raffa JD, Celi LA, Mark RG, Badawi O. The elCU Collaborative Research Database, a freely available multi-center database for critical care research. Sci Data. 2018;5:180178.

20. Dettmer MR, Damuth E, Zarbiv S, Mitchell JA, Bartock JL, Trzeciak S. Prognostic Factors for LongTerm Mortality in Critically III Patients Treated With Prolonged Mechanical Ventilation: A Systematic Review. Crit Care Med. 2017;45(1):69-74.

21. Williamson DR, Albert M, Heels-Ansdell D, et al. Thrombocytopenia in critically ill patients receiving thromboprophylaxis: frequency, risk factors, and outcomes. Chest. 2013;144(4): 1207-15.

22. Lopez-Delgado JC, Rovira A, Esteve F, et al. Thrombocytopenia as a mortality risk factor in acute respiratory failure in H1N1 influenza. Swiss Med Wkly. 2013;143:w13788.

23. Fernando G Ríos EE, Fernando Villarejo, Ricardo Valentin. Lung Function and Organ Dysfunctions in 178 Patients Requiring Mechanical Ventilation During The 2009 Influenza A (H1N1) Pandemic. Critical Care. 2011;15:R201.

24. Svensson L, Baumgarten M, Morgelin M, Shannon O. Platelet activation by Streptococcus pyogenes leads to entrapment in platelet aggregates, from which bacteria subsequently escape. Infect Immun. 2014;82(10):4307-14.

25. Xu XR, Zhang D, Oswald BE, et al. Platelets are versatile cells: New discoveries in hemostasis, thrombosis, immune responses, tumor metastasis and beyond. Crit Rev Clin Lab Sci. 2016;53(6):40930.

26. Zhu X, Wang Y, Jiang Q, et al. All-trans retinoic acid protects mesenchymal stem cells from immune thrombocytopenia by regulating the complement-interleukin-1 beta loop. Haematologica. 2019;104(8):1661-75.

27. Jansen AJG, Spaan T, Low HZ, et al. Influenza-induced thrombocytopenia is dependent on the subtype and sialoglycan receptor and increases with virus pathogenicity. Blood Adv. 2020;4(13):2967-78.

28. Koyama K, Katayama S, Muronoi T, et al. Time course of immature platelet count and its relation to thrombocytopenia and mortality in patients with sepsis. PLoS One. 2018;13(1):e0192064.

\section{Figures}




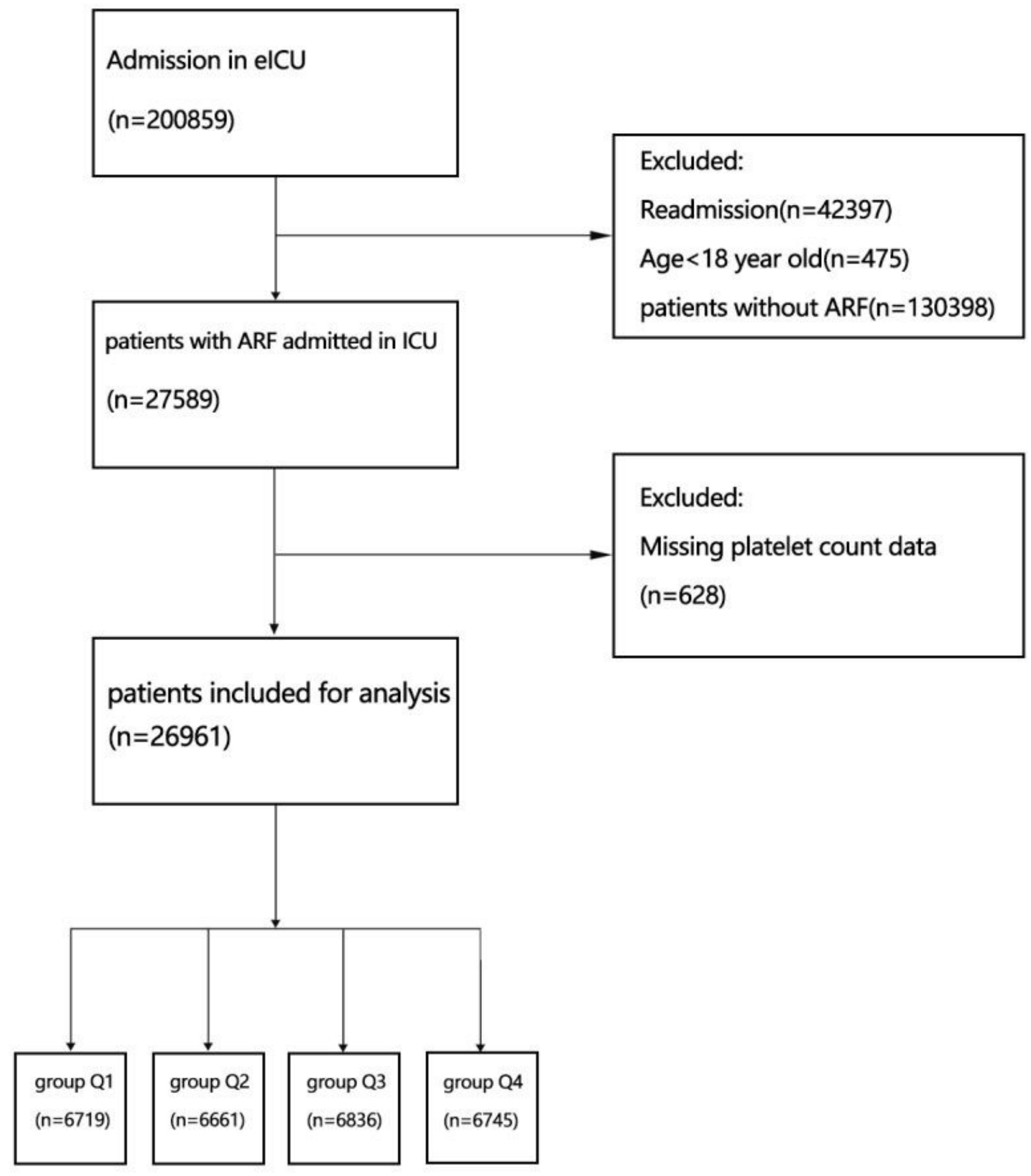

Figure 1

Flow chart of subject selection. ICU =intensive care unit, $A R F=$ acute respiratory failure 


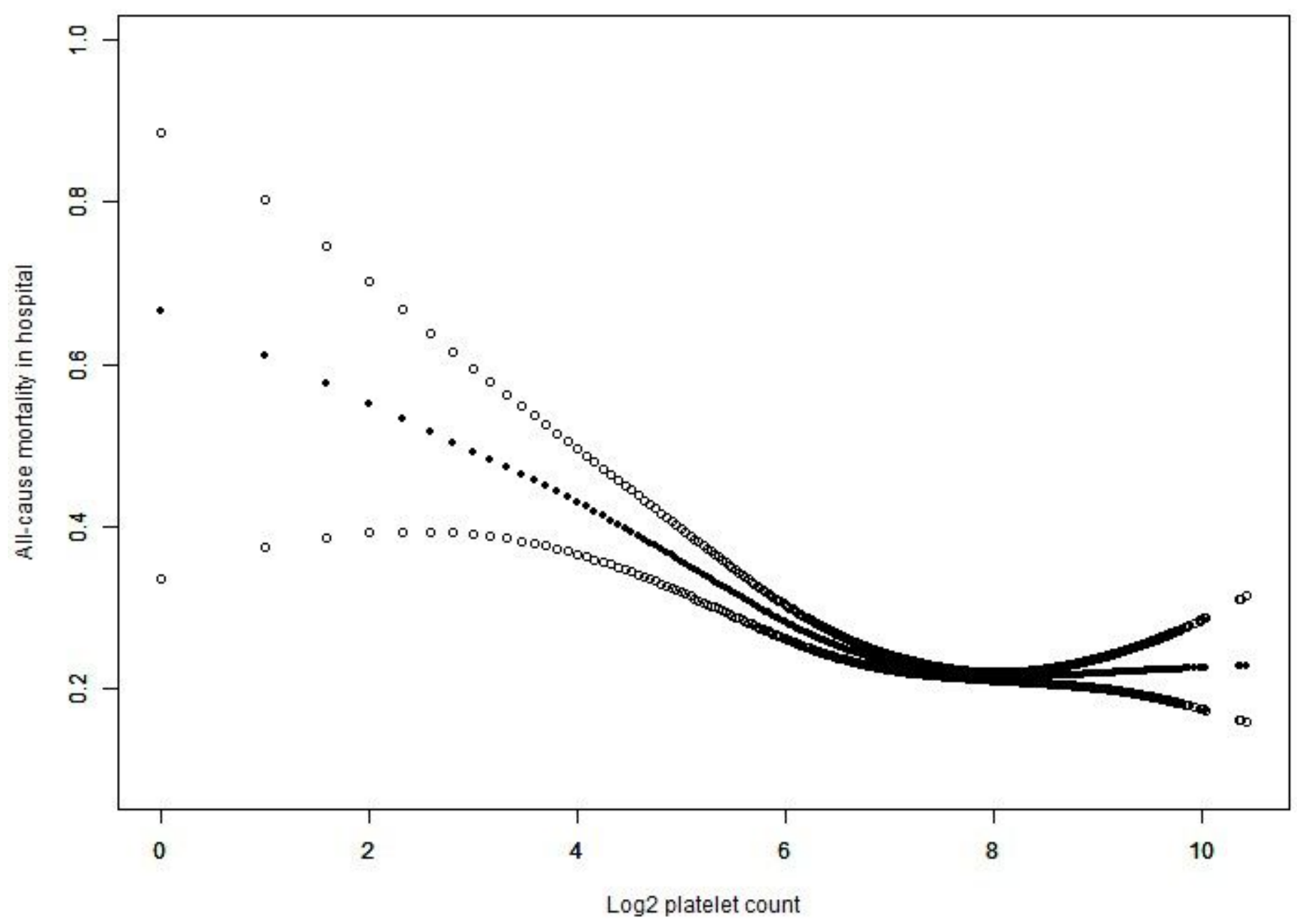

Figure 2

The correlation between log2 basal platelet count and all-cause mortality in Hospital for patients with ARF. The relationship between log2 basal platelet count and all-cause mortality in hospital were nonlinear, in which log2 platelet count was negatively associated with all-cause mortality in hospital when log2 platelet count is less than inflection point, and inflection point was shown to be between 6-8. On the right side of the inflection point, we failed to observe a correlation between log2 platelet count and all-cause mortality in hospital. 


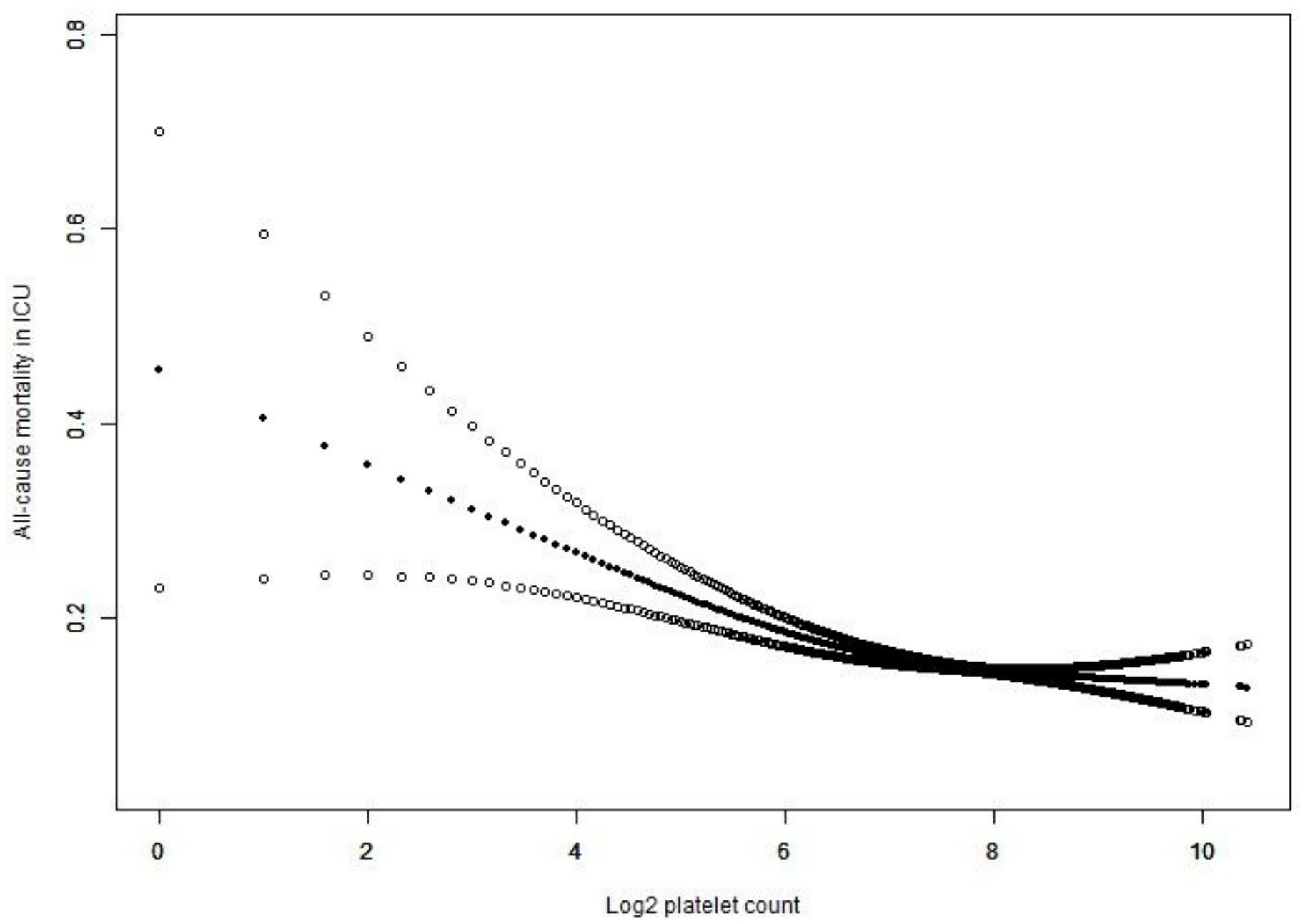

Figure 3

The correlation between log2 platelet count and all-cause mortality in ICU in patients with ARF. The relationship between log2 basal platelet count and all-cause mortality in ICU were nonlinear. log2 platelet count was negatively associated with all-cause mortality in ICU when log2 platelet count is less than inflection point, and the inflection point was visually to be between 6-8. On the right side of the inflection point, we failed to observe a correlation between log2 platelet count and all-cause mortality in ICU.ity in ICU. 